\title{
To-Do Is to Be: Foucault, Levinas, and Technologically Mediated Subjectivation
}

\author{
Jan Peter Bergen ${ }^{1}$ (D) Peter-Paul Verbeek ${ }^{1}$
}

Received: 16 May 2019 / Accepted: 12 December 2019/ Published online: 7 January 2020

(C) The Author(s) 2020

\begin{abstract}
The theory of technological mediation aims to take technological artifacts seriously, recognizing the constitutive role they play in how we experience the world, act in it, and how we are constituted as (moral) subjects. Its quest for a compatible ethics has led it to Foucault's "care of the self," i.e., a transformation of the self by oneself through self-discipline. In this regard, technologies have been interpreted as power structures to which one can relate through Foucaultian "technologies of the self" or ascetic practices. However, this leaves unexplored how concrete technologies can actually support the process of self-care. This paper explores this possibility by examining one such technology: a gamified ToDo list app. Doing so, it first shows that despite the apparent straightforwardness of gamification, confrontation and shame play an important role in how the app motivates me to do better. Second, inspired by Ihde's schema of humantechnology relations, it presents different ways in which the app may confront me with myself. Subsequently, it accounts for the motivation and shame that this technologically mediated confrontation with myself invokes through a Levinasian account of ethical subjectivity. In so doing, it also shows how Levinas' phenomenology implies a responsibility for self-care and how nonhuman, technological others may still call me to responsibility. It concludes with a reflection on the role of gamification in technologically mediated subjectivation and some implications for design.
\end{abstract}

Keywords Technological mediation $\cdot$ Levinas $\cdot$ Foucault $\cdot$ Ethics $\cdot$ Alterity $\cdot$ Gamification

Jan Peter Bergen

j.p.bergen@utwente.nl

1 Faculty of Behavioural, Management and Social Sciences, University of Twente, P.O. Box 217, 7500AE Enschede, Netherlands 


\section{Introduction}

\section{"To the things themselves!"}

Inspired by Husserl's dictum, Peter-Paul Verbeek introduced his theory of technological mediation as part of a "thingly turn," a "philosophy of artifacts" (Verbeek 2005 p. 3). As part of the postphenomenological tradition, ${ }^{1}$ mediation theory aims to take concrete, socially situated technological artifacts seriously, recognizing the constitutive role they play in how we experience the world, how we act in it, and even the way we as subjects are constituted and can constitute ourselves (Verbeek 2005, 2011). ${ }^{2}$ Drawing inspiration from, among others, Don Ihde (e.g., 1990), (Latour 1992, 1993), and Borgmann (1984), mediation theory develops a postphenomenological vocabulary with which to investigate the relations between human beings and technological artifacts and the way in which their interaction gives rise to them and their world as subjects and objects. Renouncing the a priori distinction between subjects and objects, mediation theory is explicitly amodern since it does not seek to "purify" (Latour 1993) humans and technologies. Rather, it recognizes that (moral) subjects are always shaped by technology without escape from its formative influence. As such, it can no longer uphold the modern, humanist conception of the subject, autonomous and free, with a monopoly on agency and (in principle) access to objective and universal knowledge. However, this raises at least two problems. First, does this outlook leave sufficient room for autonomy and freedom? And second, what would an ethics for mediation theory look like if humanist alternatives like deontology or utilitarianism will no longer do (Verbeek 2011)? Mediation theory has sought to answer these questions by a turn towards Michel Foucault (e.g., Dorrestijn 2012, 2017; Verbeek 2011).

This appropriation of Foucault's work is fitting given its palpable parallels to mediation theory. His insistence on power structuring the way we live, speak, think, and behave is reminiscent of technology's formative influence and attests to the difficulty of thinking the subject as autonomous. In his early work, Foucault rethought subjectivity as subjection, where subjectivity is imposed on our situated and embodied existence through "technologies of power." 3 Such power is not just negative or oppressive; it is also productive. That is, without subjection through power, there would be no subjectivity at all. While much of this work focused on the power of knowledge/discourse (e.g., Foucault 1973, 1977), Foucault realized that technological artifacts are also a potent aspect of "technologies of power," as is clear from his analysis of surveillance in Bentham's panopticon (Foucault 1977), and of the "instrumental coding of the body" through training with pencils and rifles (p. 153). For Foucault as well as for mediation theory, "technologies form a structure of power, disciplining, organizing and normalizing the subject"

\footnotetext{
${ }^{1}$ For an overview, see (Rosenberger and Verbeek 2015).

${ }^{2}$ In so doing, mediation theory distances itself both from early philosophy of technology as well as from the idea that technology is purely instrumental or morally neutral. It rejects the former, exemplified in Heidegger's (1977) question concerning technology, for thinking of technology as monolithic, overly abstract and often nostalgic (Verbeek 2005 p. 60), and it eschews the latter for ignoring the active role of technologies in shaping our experience, our lives, and morality.

3 The word "technologies" should be read here more in terms of technique, skills, methods, or rationalities that shape how we behave. For an overview of Foucault's uses of "technology" and related terms across his works, see (Behrent 2013).
} 
(Verbeek 2011 p. 70). However, this still leaves our questions unanswered. What about freedom? What about ethics?

\subsection{Foucault: Freedom and an Ethics for Technological Mediation}

In his later work, Foucault returned to the question of the subject, ethics, and freedom when, as a form of opposition to technologies of power more positive than "mere" resistance, he proposed the revival of the ancient practice of "care of the self" through "technologies of the self" (Foucault 1986, 1990). He described the latter as "those intentional and voluntary actions by which men not only set themselves rules of conduct, but also seek to transform themselves" (Foucault 1990 p. 10). This may seem odd given the flair of determinism in his early work, ${ }^{4}$ but Foucault clarifies that "[p]ower is exercised only over free subjects, and only insofar as they are free [...] The relationship between power and freedom's refusal to submit cannot, therefore, be separated" (Foucault 1982 p. 790). Thus, he submits, freedom is only possible as a practice within and in relation to power structures. He proposes the "care of the self" as such a practice of freedom (Fornet-betancourt et al. 1987) in which the goal is not to dissolve power (which is productive and ubiquitous) but to critically relate oneself to it. One cares for the self through engaging in the abovementioned "technologies of the self': transformative practices and exercises that operate through askēsis, a training of the self by oneself through spiritual self-discipline. Such is Foucault's proposal for an ethics appropriate after the "the death of man" (Foucault 1989), not as a set of rules and norms, but as an etthos: "a way of being and of behavior" (Foucault 1997 p. 286) that limits one's determination by power through subjectivation rather than subjection. This ethics of subjectivation has subsequently been appropriated by mediation theory (Dorrestijn 2012, 2017; Verbeek 2011). That is, instead of resisting technology or being determined by it, an appropriate ethics/ethos for our technological age is to be found in interaction with technologies; by exploring the ways in which technologies mediate our lives and by "finding a relation to these mediations, incorporating them in our existence, human beings can further shape and stylize their moral subjectivity" (Verbeek 2011 p. 82).

The role of technologies in this process seems clear: technologies form power structures to which one relates through Foucaultian "technologies of the self." However, this focus leaves unexplored how concrete technologies can support the very exercise of those "technologies of the self" that aid in critical self-development. Postphenomenological accounts of self-development have hitherto mainly focused on human enhancement technologies and our relation to them (e.g., Coeckelbergh 2013; Hofmann and Svenaeus 2018; Kudina and Verbeek 2018; Lewis 2018; Verbeek 2008) but have yet to elaborate on how concrete technologies could themselves support Verbeek's (2011) and Dorrestijn's $(2012,2017)$ process of subjectivation. Nonetheless, Foucault himself already affirmed the importance of such 'technologies of technologies of the self.' In Ethics: Subjectivity and Truth, he describes how ancient practices of writing (of letters, notebooks, treatises, or diaries) invited introspection and new forms

\footnotetext{
${ }^{4}$ There is no final consensus in Foucault scholarship on whether his early work is even compatible with his focus on freedom and the subject in his later publications (Mayes 2015). In this paper, we operate on the interpretation that it does, in line with the appropriation of Foucault in mediation theory.
} 
of experiencing the self (Foucault 1997). The resulting texts "served as functional devices that would enable individuals to question their own conduct, to watch over and give shape to it, and to shape themselves as ethical subjects" (Foucault 1990 p. 13). As such, these practices constituted a form of "self-writing" that was supported by concrete technical artifacts, e.g., paper notebooks, pens, ink, etc. In a postphenomenological vocabulary, these concrete technologies can thus be said to play a mediating role in our relation to ourselves and others and how we constitute ourselves therein. For example, letters are "more than a training of oneself by means of writing, through the advice and opinions one gives to the other: it also constitutes a certain way of manifesting oneself to oneself and to others" (Foucault 1997 p. 216). Additionally, Foucault already hinted at the form that such mediation takes when he explained that technologies of writing can be an "other" to the subject. Reflecting upon the notebook, he explains that "it palliates the dangers of solitude; it offers what one has done or thought to a possible gaze; the fact of obliging oneself to write plays the role of a companion by giving rise to the fear of disapproval and to shame. [...] what others are to the ascetic in a community, the notebook is to the recluse" (Foucault 1997 pp. 207-208, emphasis added).

It stands to reason that a better understanding how these technologies support practices of the self requires answering the question of how we relate to such technologies and how they are able to conjure up morally salient sentiments such as shame. Below, we provide a (post)phenomenological account of how it mediates our relation to others and ourselves and how these relations motivate us to engage in practices of the self. In this paper, we do so by investigating a modern alternative to these ancient technologies. Given that "[t]he practice of the self is established against a background of errors, bad habits, and an established and deeply ingrained deformation and dependence that must be shaken off' (Foucault 2005 p. 94), the technology analyzed here is aimed at self-improvement through self-directed guidance of action and the development of good habits, i.e., a gamified form of the ToDo list.

\subsection{A Tale of To-Do's}

The stereotypical To-Do list is simple enough. One can jot down a list of tasks to be fulfilled on a sheet of paper, thereby providing both structure and presence to those tasks. This allows for better planning, setting of priorities, and remembering that these things need doing. However, like many tools in the Information Age, the humble ToDo list has not escaped translation into virtual and elaborated form. Indeed, To-Do list

Table 1 Schematic overview of human-technology-world relations (based on Ihde 1990; Verbeek 2005)

Human-technology-world relations

Embodiment relations:

Hermeneutic relations:

Alterity relations:

Background relations:
(Human-technology) $\rightarrow$ world

Human $\rightarrow$ (technology-world)

Human $\rightarrow$ technology -(-world)

Human (-technology/world) 
apps have expanded in flexibility (in terms of structuring tasks), interconnectedness (with others and other applications like calendars and social media platforms), and presence (in terms of the omnipresence of devices and the intrusiveness of notifications). However, some To-Do list apps have gone even further by purposefully including elements that are meant to motivate users to fulfill tasks set by them. This paper discusses one such app that claims to motivate its users by employing gamification, using game elements in the nongame context of everyday life (Deterding et al. 2011): Habitica.

\subsection{Habitica and the Gamified Life}

Habitica is meant to be a "habit-building and productivity app that treats your real life like a game". It turns life into a role-playing game (RPG) in which the habits you want to develop, daily tasks, and other tasks on your To-Do list are treated as "monsters" that one('s virtual character) must defeat, gaining experience, virtual gold, new gear, and other rewards in the process. It is also possible to join up with others in "parties" or "guilds" and battle "bosses" like the "SnackLess Monster" or the "Laundromancer" together. Even the visual style reminds one of old-school computer games (see Fig. 1).

Of course, at a basic level, Habitica simply turns aspects of everyday life (fulfilling habits, daily activities, and To-Do's) into game data and presents them back to its user. This places Habitica squarely in a general trend ${ }^{6}$ where, through the use of smart phones and other tracking devices, "measuring and tracing aspects of the 'personal' and 'the everyday' is becoming more commonplace," which in turn "contribute[s] to opening a widening field of everyday life to scrutiny and intervention, connecting with the theme of self-optimization" (Ruckenstein 2014 p. 6869). Such tracking technologies generally present us with "data doubles" that, after situated and active interpretation and reflection, allow for new ways of understanding, acting upon, and relating to ourselves (Pantzar and Ruckenstein 2017; Ruckenstein 2014; Sharon and Zandbergen 2017). However, as indicated above, many of these applications go further than simply "producing data" that users can relate to and purposely include features meant to motivate users to engage in specific self-optimizing practices, ${ }^{7}$ such as "target numbers, risk scores and gamified incentives" (Pantzar and Ruckenstein 2017 p. 2, emphasis added). Indeed, many self-tracking apps, including apps aimed at improving productivity, use game elements to help motivate users to do things they would otherwise not (Hamari et al. 2014). ${ }^{8}$ With Habitica aiming to improve productivity by treating its users' lives like an RPG, it has clearly chosen such gamified incentives as the mechanisms by

\footnotetext{
${ }^{5}$ From https://habitica.com/, accessed 15/10/2018.

${ }^{6}$ The trend refers mainly to the increasing ubiquity and reach of self-tracking technologies, also known under rubrics like "personal analytics" or the "quantified self." However, self-tracking through technology is in fact not new but has an extensive history (see Crawford et al. 2015).

7 This does not mean that "simply" being presented with data cannot motivate users. The mere opening up of new hermeneutic and practical possibilities may already present a sort of general, "existential" responsibility to make new choices for the self-tracking subject (Van Den Eede 2015). The analysis in this paper may help to explain how that is possible.

${ }^{8}$ Gamification is of course not limited to applications concerning health or productivity. Over the years, it has aroused both practical and theoretical interest from a variety of disciplines (see Seaborn and Fels 2015).
} 


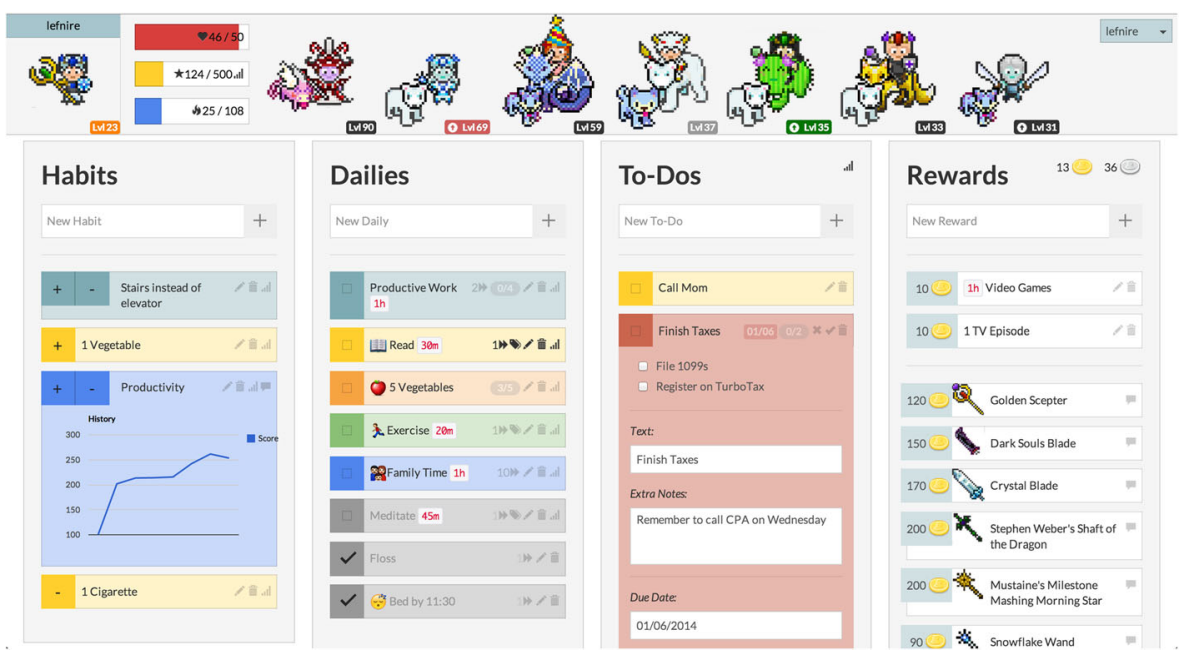

Fig. 1 Habitica's task overview (from https://habitica.com/static/features)

which it wishes to motivate them to work on themselves. It is no coincidence, then, that its format employs many of the standard tools in the gamification toolbox, such as documentation of behavior, score systems, levels, quests, group tasks, avatars, and virtual worlds (Blohm and Leimeister 2013), with the "leveling" of the users avatar (Habitica's most prominent "data double") metaphorically embodying the underlying teleology of self-improvement. Together, these mechanisms of gamification are supposed to motivate users of Habitica by providing positive and negative reinforcement in favor of behaviors that are in line with the tasks the user has set for herself/himself, habituating those set for repetition (Robson et al. 2015; Skinner 1938; Steffen et al. 2015). Armed with the power of operant conditioning, then, Habitica aims to change its users' lives for the better.

At the same time, however, there is something terribly amiss in that description. That is, the behaviorist schema of punishments and rewards incorporated into Habitica's "gameplay" fails to account fully for the motivation that it invokes. There is something more visceral about using of Habitica that pushes me to do better. This is not "just a game." The stakes are high: they are me, my responsibilities, and my personal development. On top of this, there is also something rather peculiar about the way in which I experience and relate to the game and, in so doing, to myself. As the analysis in this paper aims to show, its role in subjectivation can be illuminated through investigating these additional aspects of the gamified To-Do-list. Notably, the way we conduct this investigation is already foreshadowed in the tonal shift that characterizes this paragraph. Rather than speaking in first person plural as the authors ("we"), our (post)phenomenological approach to investigating technologically mediated subjectivation requires a methodological shift to the subjective, first person perspective ('I/me/myself') for describing experiences and/or phenomenologically salient aspects thereof. As such, the analysis in the following sections is steeped in that perspective, starting with the description of experiences with Habitica below. When clarifying issues 
of methodology or procedure, and when summarizing or concluding, however, we do revert to speaking from our position as authors. ${ }^{9}$

\subsection{Confrontation, Objectification, and Ascetic Practices}

The following paragraphs describe experiences with Habitica and how it gets me to focus on the tasks I set myself rather than doing more immediately gratifying activities. The latter are seductive to me, as I tend to procrastinate. This often takes the form of sifting through social media feeds and gorging on online media, while sinking into my chair and letting my covetous eyes and hands take over, inadvertently scrolling or clicking on to one more video. While I am doing so, I am not concerned with myself. Rather, I am (temporarily) carefree, not because the videos are more important than my goals but because in a seemingly never-ending stream of them, I lose track of my surroundings, of time, and even myself. That is, I am relieved and content.

However, at some point, whether by seeing its logo on my smartphone screen, the bookmark in my browser, or the notification that Habitica sends me, I am suddenly confronted with my own gluttonous behavior. I "walk in on myself" and do not like what I see, an unpleasant wake-up call. I am ashamed before myself and others (e.g., party members). The app even shows me that I have done myself short. My avatar has lost health points and is hurt. I(t) am/is no longer healthy. Even worse, my party members might have "taken damage" as a result of my lackadaisical conduct. At a glance, however, I see how I can redeem myself. My task list is right there. Habitica not only shows me a representation of me that shows me hurting myself but provides the terms in which I need to understand myself and the road to self-betterment. It provides a roadmap in terms of ascetic practices (determined by me) that I can undertake, ascetic since I would have to undertake them in spite of myself (or at least the part of me that wants to watch more motorcycle videos), and habituating them requires discipline on my part. Apparently inadvertently, however, I end up falling back into some bad habits. And the process repeats itself, even if I am now closer to gaining another "level," representing the fact that I have supposedly "improved." As such, the process of selfimprovement starts in enjoyment being questioned in a confrontational moment. After this, I am thematized in such a way that my shortcomings become clear and can be overcome. These moments lead to episodes of ascetic practices or, in Foucaultian terms, technologies of the self, which in turn serve to improve myself, to consciously subjectivate (at least in Habitica, since I determine the content and quantity of these practices). Once on its way, the process oscillates between these episodes and moments, between ascesis falling back into enjoyment, punctuated by confrontation which again invites practices given shape in moments of objectification. ${ }^{10}$

\footnotetext{
${ }^{9}$ One might object to such a "methodologically constructed" first-person perspective because multiple authors cannot speak through it. However, not only are the descriptions of experiences with Habitica based in the substantive use of the app by one of the authors, but phenomenological descriptions simply cannot proceed from the position of a "we." We, the authors, may have our own experience with technologies like Habitica in our capacity as subjects (which we can synthesize into a first person narrative), but the "we" (an abstract entity constructed in writing) does not.

${ }^{10}$ Note that this does not mean that ascetic activities cannot be enjoyable. It simply means that I would never have started them without the confrontation.
} 
Some of the elements described above are compatible with the mediation theory's ethics of subjectivation, especially concerning introspection (e.g., choices in character development, both virtual and real), self-writing (in terms of habits and dailies), and the support for ascetic, disciplined practices. As such, Habitica may be able to support the exercise of technologies of the self. However, there are at least two related aspects that require further explanation. First, if it is to support an ethics of self-care for mediation theory, the way in which the technology helps mediate my relation to myself needs to be further explored. Secondly, and more interestingly, neither mediation theory nor its Foucaultian ethics of subjectivation fully account for the motivating force of the confrontation with myself. Both of these aspects are explored below, starting with the former.

\section{A Postphenomenological Classification of Technological Confrontation}

Somewhat surprisingly given mediation theory's Foucaultian ethics of subjectivation, the structure of such technologically mediated, confronting relations has not received much attention in the literature. This section aims to partially overcome that deficit by examining different roles that Habitica plays in motivating me to do better.

As the example of Habitica shows, some technologies can aid in self-improvement by confronting me and providing me with representations of myself. In using Habitica, these confronting and objectifying "moments" usually coincide, immediately constituting me as the possible object of self-improvement. However, not all experiences of confrontation with Habitica involve both. To clarify this further, this section presents different ways in which Habitica manages to confront me with myself, with or without presenting representations of myself (leaving the task of my objectification to me, others, or technology). To do so, we draw inspiration from Don Ihde's (1990) postphenomenological reflections on the mediating role of technologies in humanworld relations, of which he identified four: embodiment, hermeneutic, alterity, and background relations. In embodiment and hermeneutic relations, I experience and act upon the world through technologies, albeit in different ways. In alterity relations, the technology is instead fully present and the central focus of my experience. Finally, in background relations, the technology forms the backdrop of my experience and actions. In schematic form, these can be illustrated as follows (see Table 1).

Below, we represent the relation with Habitica in a format similar to Don Ihde's human-technology-world relationships but focused on Habitica's mediation of my relationship to myself, i.e., as variations of I-technology-[I/self] relations. ${ }^{11}$ In these descriptions, [self] indicates a concrete representation of me to which I relate, whereas $[I]$ indicates myself simply as being-there in the situation. In so doing, we also wish to

\footnotetext{
${ }^{11}$ The use of square brackets for [I/self] is motivated by two considerations. First, it visually emphasizes the object of the relations this paper explores, i.e., confrontations with oneself. Secondly, it indicates the peculiarity of the self-relation. That is, unlike how one experiences other things, one cannot experience oneself as an object simpliciter, disconnected from its own existence as experiencing oneself. Experiencing oneself, even as an object of knowledge, cannot succeed as an escape from oneself. Rather, "[ $t$ ]he I always has one foot caught in its own existence. [...] It is forever bound to the existence which it has taken up [...] it is riveted to its own being" (Levinas 1978 p. 84).
} 
emphasize the specificity with which Habitica turns our attention to certain aspects of ourselves and our lives (e.g., bad habits) by recognizing that Habitica exhibits strong technological "intentionality" (Ihde 1990). This concept refers to the "specific ways in which specific technologies can be directed at specific aspects of reality" (Verbeek 2008 p. 382) and encourages or promotes certain ways of acting. When this technological intentionality is added to human intentionality, a "composite intentionality" results (Verbeek 2008), which allows experience of and actions upon the world (or in the case of Habitica, myself) hardly possible without my intentionality coming together with the technology's. As such, whereas human intentionality is indicated by double lined arrows (=>), Habitica's specific "directedness" is represented below with single line ones $(\rightarrow)$. Following this general format, the following paragraphs present four different types of confrontational relations with Habitica. ${ }^{12}$

First, Habitica often confronts me with a representation of myself. This means that the confrontational and objectifying moments coincide. However, the representation of me and I do not coincide, hence the confrontational nature of the moment. In other words, I am presented with an image of (aspects of) myself that is other to me. I am other to myself and this discrepancy may call me to action, especially given that Habitica's technological intentionality is aimed at generating a "data double" that will induce that effect. To use Ihde's vernacular, the distinct hermeneutic relation I engage in with Habitica allows for an alterity relation to (my)self.

$$
I=>\text { (technology } \rightarrow \text { [self }])
$$

Secondly, Habitica may provide other or others who call me to responsibility, either by mediating my contact to real others (e.g., Habitica party members that depend on my diligence) or by emulating others (e.g., the virtual Habitica avatar that tells me I "ran out of health" and that I can get my rewards back with "hard work"). Habitica's technological intentionality is again relevant here because Habitica tends to (re)present others specifically as confronting and/or demanding, which in turn shapes the way that confrontation relates back to myself and the actions I must undertake. In the case of mediating my access to a real other, there is a hermeneutic relation towards this other since they are represented in a specific way while simultaneously provoking an alterity relation to this particularly represented other that is confronting and turns my attention back onto myself:

I $=>$ (technology $\rightarrow$ Other) $\rightarrow[\mathbf{I}] /[$ self $]$ (depending on the provision of selfrepresentation)

Whereas in the case of it merely emulating other, I am instead directly confronted by that technological other:

\footnotetext{
$\overline{12}$ This list is not exhaustive, since it focuses on confrontational relations in which Habitica seems to play a central or active role. As such, it does not engage with the possible confrontational moments in thinking of and writing down the habits one would like to cultivate, a process which is nevertheless mediated by Habitica. However, as "classic" postphenomenology (as we employ it here) is less adept at clarifying processes of writing than it is of reading and interpreting (Wellner 2018), their inclusion would likely have us stray from the central goal of the paper.
} 
I $=>$ technology/other $\rightarrow[\mathbf{I}] /[$ self] (depending on the provision of selfrepresentation)

Finally, there are situations where Habitica induces confronting moments while not providing input as to what those mean for me or what I am to do about them. For example, there are cases where there is a certain function that I cannot get to work properly. I've looked through the menus and clicked the buttons I thought relevant, and I am still not getting where I want to. I might blame this on the app itself or on its programmers. However, I might also realize that the problem is me. Maybe I do not have as much of a knack for virtual carousing as I thought I had. If so, the problematic situation with Habitica turns into a problematization of me. This time, however, there is little to no thematic representation of me by the technology as Habitica's technological intentionality plays little role here. In that case, this relation can be formalized as:

$$
\mathbf{I}=>\text { technology }=>[\mathbf{I}]
$$

Strictly speaking, the I-technology relations involved in these examples vary in the way confrontation with myself comes about. In the first example, there is a combination of alterity and hermeneutic relations, since it provides a way of understanding myself, but as an other to me. In the second example, there is a hermeneutic relation where Habitica mediates my relation to others (e.g., by setting them up as party members), with whom I am subsequently in an alterity relation. And in the last example, I am in an alterity relation to Habitica since it becomes frustratingly vorhanden (Heidegger 1962). However, there is also a common characteristic of these relations: all of them involve me falling into a critical relation to myself (with or without explicit representations of $\mathrm{me}^{13}$ ), which is in line with Foucault's description of the way in which notebooks and letters support practices of the self.

This short postphenomenological exploration identified different roles for technologies like Habitica in confrontation with myself. However, it has not shown how confrontation motivates me to better myself and what role enjoyable procrastination and self-knowledge play in it. To account for the constitutive role that confrontation can have in technologically mediated subjectivation, we submit that it may be helpful to complement mediation theory's Foucaultian schema of self-care with another account of subjectivity. Specifically, in the following sections, we show how subjectivity in Emmanuel Levinas' ethical phenomenology is fundamentally constituted by confrontation and also ends up recommending deliberate and never-ending self-development.

\section{A Levinasian Subjectivity for the Care of the Self}

At this point, a turn towards Levinas may seem peculiar given Foucault's own reservations concerning phenomenology. As Foucault himself explained with regard

\footnotetext{
${ }^{13}$ There seems to be a difference between evaluative representations (e.g., showing your "health age" based on your lifestyle) and aspirational representations which provide an image of myself towards which I am motivated to work. The realization of my current shortcomings is more direct with the former and more indirect with the latter. As such, aspirational self-representations can be said to be only derivatively confronting.
} 
to the study of history: "[i]f there is one approach that I do reject, however, it is that (one might call it, broadly speaking, the phenomenological approach) which gives absolute priority to the observing subject, which attributes a constituent role to an act, which places its own point of view at the origin of all historicity - which, in short, leads to a transcendental consciousness" (Foucault 1989 p. XV). Nevertheless, a turn towards Levinas is appropriate here, for several reasons.

First, this turn towards Levinas is partially pragmatic. The aim of this paper is not Foucaultian exegesis but rather understanding the role of technologies in an ethics for mediation theory. A Levinasian perspective is informative here because it is compatible thematically (e.g., linking confrontation, alterity and ethics) and methodologically (since, as postphenomenological, mediation theory remains committed to subjective experience, even if it is always situated and relationally constituted). Secondly, Foucault's criticism of phenomenology might not even be applicable to Levinas. After all, it is mainly aimed at Husserl's phenomenology, ${ }^{14}$ about which Levinas had his own reservations that (like Foucault's) include doubts about the self-sufficiency of the subject and the primacy of action. And while Levinas and Foucault resolved these issues differently, Levinas' conception of subjectivity (see below) does not fall prey to Foucault's objections. Thirdly, some have even argued that Levinas' reflections on ethics might be of added value to a Foucaultian perspective because the priority that Foucault gives to the self in ethics allegedly "poses serious problems for efforts to think forms of contemporary subjectivity and ethics" (Oksala 2005 p. 194). ${ }^{15}$ To be sure, Foucaultian self-care is not blatantly egoist since it inevitably involves caring for others. Nevertheless, he maintained that "[o]ne must not have the care for others precede the care for self. The care for self takes moral precedence in the measure that the relationship to self takes ontological precedence" (Fornet-betancourt et al. $1987 \mathrm{p}$. 118). While this may be sufficient for establishing an "aesthetics of life," it is doubtful whether it provides an "ethical subjectivity that would still make ethics meaningful" (Oksala 2005 p. 205). In Levinas, on the other hand, ethical subjectivity is what makes society, discourse, and care for the self and others possible in the first place. Where Foucault taught us that "ontology is politics that has forgotten itself" (Oksala $2010 \mathrm{p}$. 464), for Levinas, a politics reduced to an interplay of power(s) is itself forgetful of the responsibility that inspired it.

On the one hand, then, this paper turns to Levinas because doing so clarifies our experience with Habitica. On the other hand, it could also provide an ethical foundation for subjectivation in mediation theory that is still nominally compatible with the latter's Foucaultian outlook. In the following sections, we first lay out Levinas' thinking on enjoyment, confrontation, shame, and their role in the formation of ethical subjectivity. Subsequently, we indicate how Levinas' ethics leads to the possibility and responsibility to care for oneself and how this links up to politics and power. Finally, we provide an account of how, contrary to Levinas' own writings, technologies like Habitica can call us to responsibility in the Levinasian sense of the word.

\footnotetext{
${ }^{14}$ Despite Foucault's objections, a number of his criticisms (e.g., the subject as being both transcendental and empirical) were already recognized and taken up by Husserl and others. As such, there are also significant parallels between Foucault and phenomenology. As Oksala argues: "Foucault's work should not be seen as a total break with phenomenology but rather as part of a continuum, even if the relationship is fundamentally critical" (2005 p. 54).

${ }^{15}$ For a contrary account, see Hofmeyr $(2003,2006)$.
} 


\subsection{Confrontation: Subjectivity Between Enjoyment and Responsibility}

As indicated above, both enjoyment and confrontation are constitutive elements of a Levinasian account of subjectivity. While it is neither possible nor fruitful to give an exhaustive analysis here, the following paragraphs provide a rough outline of such an account.

For Levinas, the ego first arises through a "radical separation" (Levinas $1969 \mathrm{p}$. 54) between it and the world, which is established as a "living-from" that world (p. 110), which is characterized by enjoyment. ${ }^{16}$ The ego enjoys the world by taking it into itself, which provides "nourishment, as a means of invigoration" (p. 111). This enjoyment of the world is not (yet) an understanding or possession of it. Enjoyment operates in the realm of sensibility, and it is pre-reflective and vibrates beneath consciousness. It is "not a psychological state among others [...] but the very pulsation of the I" (p. 113), which exists "for itself [but is not] a representation of self by self" (p. 118). The ego is thus not a thing among things; its substantiveness, if any, is to be found in enjoyment, ${ }^{17}$ as a self-sufficiency, a plenitude and a fulfillment, naïve, egoistic, and solitary but nevertheless content. In the same breath, the world "'materializes' in satisfaction, which, over and beyond any intentional relationship of cognition or possession [...] means 'biting into..." (Levinas 1981 p. 73) ${ }^{18}$ That is, in enjoyment, the world becomes matter by mattering to me as nourishment, even when enjoying it through vision or audition (Levinas 1969 p. 187). Such enjoyment of the world is not characterized by the ego's intentionality or actions, but rather its sensuous susceptibility to being affected, a vulnerability (ibid.). It is this susceptibility that makes it possible to "enjoy without utility, in pure loss, gratuitously [, which] is the human" (Levinas 1969 p. 133). With this, Levinas provides the grounds for an embodied human subjectivity (ibid. p. 114) without reference to biological or sociological categorizations. At the same time, he establishes that everyday things, including technologies, can be the substance of enjoyment: "[w]e live from 'good soup,' air, light spectacles, work, ideas, sleep, etc... [...] The things we live from are not tools $[\ldots]$ They are always in a certain measure - and even the hammers, needles and machines are - objects of enjoyment, presenting themselves to 'taste', already adorned, embellished" (Levinas 1969 p. 110). As such, neither the ego nor the world in/from which it lives is somehow "neutral ground," simply "being." Rather, they are always already axiologically saturated: "the morality of "earthly nourishments' is the first morality [...] It is not the last, but one must pass through it" (Levinas 1987b p. 64).

Crucially, the ego does not and cannot go beyond the "morality of earthly nourishments" alone. Instead, this "first morality" is revealed to be unjustified

\footnotetext{
${ }^{16}$ In the original French, Levinas uses the word jouissance, which means intense pleasure, with connotations to sexual pleasure as well as pleasure derived from understanding or of the (right to) use of one's possessions.

${ }^{17}$ As Levinas says, "the ' $\mathrm{I}$ ' is not initially an existent but a mode of existing itself, that properly speaking does not exist" (Levinas 1987b p. 53).

${ }^{18}$ In Totality and Infinity, Levinas focuses on the hand as an organ for labor, for taking possession, for "domination, mastery, disposition" (Levinas 1969 p. 161). Nevertheless, the hand can partake in enjoyment too, not when "grasping" the world but in its tactile sensibility.
} 
and imperious in the face of the infinitely (and in Levinas, usually human) other. Other than the things from which I live and which I enjoy, the other resists the ego's attempts at mastery and remains always beyond its grasp (e.g., Levinas 1969 p. 39). Rather than being determined by me, it presents and expresses itself, as an epiphany (Levinas 1969), "makes an entry" into being (Levinas 1986) from beyond being (Levinas 1981). This epiphany of the other manifests itself as its face, which, rather than representing the physical face [visage], denotes the other's apparition in expression. It imposes itself by addressing the sensitive ego (through both verbal language and bodily expression) and in so doing shows itself as vulnerable and hungry, itself susceptible to suffering in its very nudity and destitution (Levinas 1969, 1981, 1996, 1998). The resistance of the other expressed in its "defenseless eyes" (Levinas 1969 p. 199) opposes me, overwhelms my very egoism, and puts me in question (Levinas 1986 p. 351-353). It is "an attack made immediately upon the plenitude of the complacency in oneself [..., on the identity in enjoyment" (Levinas 1981 p. 74). However, this confrontation is not a violence. It does not operate through the exercise of power. Rather, it has "a positive structure, ethical" (Levinas 1969 p. 197).

This "election" by the other, which calls me to action "despite myself" (Levinas 2000 p. 100), does not leave the ego unscathed. It has become "at odds with itself in its return to itself" (Levinas 1981 p. 124), which is accomplished as shame (Levinas 1969 p. 84); it is transformed from being "for itself" to being "one-forthe-other" (Levinas 1981), "responsibility through and through" (Levinas 1996 p. 12). This has important implications. First, the subject's responsibility provides it with an inescapable uniqueness (Levinas 1969 p. 245). Secondly, as one-for-theother, the Levinasian subject is heteronomous, never entirely its own. Only by addressing and giving to the other the subject "hovers over its own existence" creates distance to itself, its life, and its "animate body, "and its enjoyed possessions gain their proper gravity and signification (p. 210). Combined, the unicity of the subject and its "de-nucleation" or fission (Levinas 2000 p. 138) allow for selfconscience and for freedom, albeit a paradoxical freedom that is "immediately limited by its responsibility" (Levinas 1987b p. 55). On this Levinasian account, the subject is responsible before it is free, and freedom consists of "the possibility of doing what no one can do in my place; freedom is thus the uniqueness of that responsibility" (Levinas 1981 p. 181).

A such, enjoyment and confrontation by the other are the main constitutive elements of an embodied subjectivity, susceptible to others, with responsibility driving it outward and forward. And that subjectivity and responsibility are accompanied by shame when faced with an other, as the Foucaultian subject was in its encounter with the notebook. However, this is still a different subject than Foucault would have it; it is not a social or political subject, shaped by and in terms of power/knowledge networks. As such, it is also not (yet) capable of engaging in the reflective "technologies of the self" Foucault proposes. Luckily, and despite his focus on the themes above, Levinas does provide a number of helpful insights on the transformation of subjectivity in social life that, at least prima facie, transform Levinas' ethical subjectivity into a political subject that is more compatible with Foucault's conception of it. 


\subsection{On the Possibility and Responsibility to Work on Oneself}

In Levinas' further reflections on sociality, politics, and justice (which, likely due to his own focus on responsibility, are often overlooked ${ }^{19}$ ), one can find the outlines of a subject thoroughly mediated by its encounter with others in a social/political setting. Indeed, in everyday life, I am not just faced with a single other, but many other Others for whom I am also responsible, each one as unique as the first. The entry of such a "third party" disrupts the straightforward immediacy of the responsibility for the other and gives birth to the first problem (Levinas 1981): the question of justice. What am I to do? To whom and how do I respond?

Answering such questions inevitably requires the comparison of others "in the very name of their dignity as unique and incomparable" (Levinas et al. 2007 p. 206). It introduces weighing and evaluation, "[...] coexistence, contemporaneousness, assembling, order, thematization, [...] the intelligibility of a system" (Levinas 1981 p. 157). It requires grasping others in terms of their quiddity, apprehending the infinitely other in finite terms (Levinas 1969 p. 177), rendering them knowable, interchangeable, judgeable, etc. This relation to others gives rise to "the We, aspires to a State, institutions, laws, which are the source of universality," i.e., to politics (Levinas 1969 p. 300); a movement necessary for justice but in which dealing with others risks being reduced to "grasping the individual, which alone exists, not in its singularity which does not count, but in its generality, of which alone there is science" (Levinas 1987a p. 50). Indeed, the thinking required by justice also expresses itself in science and technology, providing additional ways of understanding and regulating others, the world, and their relations to one another. ${ }^{20}$ Through the optics of politics and technology, human others are presented as beings, cloaked by "a language that composes a mask called a person, someone or no one [...] at the limit a personality endowed with purely empirical consistency" (Levinas 2003 p. 45-46). Such understanding of others in general terms is not simply "their comprehension, but also their being taken in hand, their domestication, their possession. [...] Reason, which reduces the other, is appropriation and power" (Levinas 1987a p.50). As such, knowledge and power are inextricably linked (as they are in Foucault), and objectification constitutes "a great betrayal" of the other (Levinas 1969 p. 44) which is nevertheless necessary for justice. And it is this dilemma at the heart of what it means to be in society that should motivate me to remain susceptible to the other and criticize and improve our techno-political systematizations accordingly, ad infinitum (Bergen 2017).

\footnotetext{
${ }^{19}$ For example, Hofmeyr (2006) locates Levinas' care of the self at the level of enjoyment and thus renders it essentially egoist. Hence, it would be condemned to amorality without the other. Notwithstanding the fact that the latter critique would also apply to a Foucaultian subject, this paper shows that self-care in the sense of working on oneself is not located in enjoyment but in justice and is thus always already deeply ethical.

${ }^{20}$ Levinas does see politics, science, and technology as intertwined (e.g., Levinas 1981 p. 161, Levinas 1994a, 1994b) but often discusses them separately. Levinas mainly sees technology as setting up the world as "raw materials" for justice and as a secularizing force that should allow humanity to come together more sincerely. $\mathrm{He}$ is also acutely aware, however, of the potential of politics and technology to enslave others, threatening their identity and dignity (Bergen 2017).
} 
However, the subject is also transformed in techno-politics because in it "I must think [and] become aware", which is the "birth of consciousness" (Levinas 2000 p. 183). And having gained consciousness, I can take not only the other but also myself as the object of understanding, power, and concern. I might even have to: "my responsibility for all can and has to manifest itself also in limiting itself. The ego can, in the name of his unlimited responsibility, be called upon to concern itself with itself" (Levinas 1981 p. 128). The question of "[h]ow to be?" (Levinas 1981 p. 75) requires never-ending reflection on my being (in the continually evolving terms of the "social superstructure" [Levinas 1981 p. 181]), on what I am to the neighbor and the third party. And it is thus, in society and in the name of justice, that I "shall again find the law and, by way of the law, autonomy and equality" (Levinas 2000 p. 181, emphasis added). Only in society can I concern myself, because" justice can be established only if I [...] can become an other like the others" (Levinas 1981 p. 160-161). However, this is not without danger: the responsibility for the other that motivates justice can be forgotten in our political/ technological equivocation. When this happens, "consciousness is born as a pure possession of self by self, yet this egoism, or egotism, is neither primordial nor ultimate"(Levinas 2000 p. 183). In other words, taking the self-relation as ontologically prior to relations with others, as Foucault did (Fornet-betancourt et al. 1987), would for Levinas constitute a forgetting of the responsibility that made this "ontological" self possible in the first place.

In sum, we find in Levinas a political subject that can know itself and is motivated to reflect and work on itself. In other words, Levinas describes a subject that is eventually subject to socially situated power-knowledge structures and can nevertheless engage in care of the self. But, in contrast to the Foucaultian subject, it should do so in light of its responsibilities for others. Still, a question remains: which others can confront me and induce responsibility? Is it only human others (as most of Levinas' oeuvre implies), or might there be some room for Habitica yet? In the following sections, we show how not only human others can call me to responsibility, but technological others like Habitica can do so too, albeit derivatively.

\section{Habitica, Alterity, and Ethics}

The Levinasian account of subjectivity sketched above provides an explanation for the motivational force of confrontation, where it is ultimately the confrontation with Others that motivates my care of myself. This dynamic seems to run parallel to confrontation in using Habitica, i.e., it induces a call to responsibility rather than a resistance against structures imposed upon me. On top of all this, it provides a central role for enjoyment in becoming a moral subject. On the other hand, it is not at all clear that, on a Levinasian account, a technology would be capable of calling me to responsibility at all. Indeed, throughout his writings, he makes it abundantly clear that it is the human Other that is the Other par excellence. Nevertheless, I seem to be called to responsibility by Habitica. How are we to understand this link between technology, its alterity, and its possible link to Levinasian responsibility? 


\subsection{Technology's Alterity}

In his own work, Levinas offers the observation that sometimes, objects can have a sort of alterity, can "present" as if "objects on exposition", with "something like a façade" (1969 p. 193). Derived from architecture, the façade denotes the way in which objects of beauty, of art, are a "pre-eminent exhibition" with a "shamelessness capable of holding all looks for which it is exclusively destined" (1981 p. 40). Yet, this is not the face of an Other. While art, like the Other, is not enjoyed as a satiation of a need, it does not signify in the same sense that the Other does (to whom I cannot be indifferent). Rather, "in it is constituted the beautiful, whose essence is indifference, cold splendor, and silence" (1969 p. 193). As such, if Habitica indeed calls me to responsibility, it cannot do so purely through some "esthetic" effect. Another possibility offered by Levinas is that cultural or technological objects can disturb my enjoyment and inspire responsibility to the extent that they are, as an example of work ${ }^{21}$ by the Other, a trace of the Other ${ }^{22}$ (e.g., Levinas 1987a). From behind these objects, the Other's nakedness shines through. In a world of artifacts, then, my appropriation of them is always a reminder of others (albeit as illeity, in the third person) and my responsibilities. Nevertheless, like the façade, the trace does not seem to explain the experience of confrontation in Habitica, given that we have no reason to assume that Habitica is particularly translucent to its developers' trace, thus providing no reason why it is exceptionally confronting. However, even if Levinas did not provide a clear answer to the question at hand, others have been inspired by his work to try and do so.

Some have argued that technologies can be Others in the Levinasian sense. For example, Gunkel (2012,2018) and Coeckelbergh (2014) claim that at least some technological entities that are part of the social fabric, like machines or robots could be, are worthy of moral consideration. ${ }^{23}$ They base this position on a relational approach to ethics that is explicitly inspired by Levinas. For them, excluding robots from the realm of ethics is based on our ontological presuppositions on what it means to be a machine, which would blind us to the robot's alterity. In so doing, they essentially accuse Levinas of being insufficiently Levinasian, his anthropocentrism not supported by the very logic of his own ethical phenomenology. ${ }^{24}$ Introna (2010) broadens the scope of the ethical community even further, suggesting with Harman (2002) that all inanimate objects are, in the fullness of their being, always "more than that which human intentionality brings to it" and thus also "infinitely other" (p. 98). Neither of these options is satisfactory either. Not only does Introna's proposal fail to provide a reason why Habitica is particularly responsibility-inducing, but the kind of

\footnotetext{
${ }^{21}$ According to Levinas, a work is "a movement of the Same towards the Other which never returns to the Same" (1987a p. 91). To produce a work means to open it and myself up to the Other, which excludes the possibility of work being a mere game and of any guarantee that the work is mine to appropriate, keep or define. Work is always already invested in the Other and thus ethically charged and social.

${ }^{22}$ Artifacts can be traces of the Other only derivatively. The original trace is not a sign of something present ("does not belong to phenomenology" (Levinas 1986 p. 356)) but signifies through what is always already passed, absent: the infinitely Other. The trace of the Other "does not begin in things, which by themselves do not leave traces but produce effects, that is, remain in the world. When a stone has scratched another stone, the scratch can, to be sure, be taken as a trace, but in fact without the man who held the stone this scratch is but an effect" (ibid. p. 358).

${ }^{23}$ For an applied and empirically informed exploration of similar themes, see Bottenberg (2015).

${ }^{24}$ As these authors note, this line of criticism is not new and was famously presented by Derrida (2008).
} 
infinite alterity that he is eyeing, i.e., one of the perpetual mystery of beings, is also incompatible with Levinas' thinking of alterity "otherwise than being." 25 The proposals by Gunkel and Coeckelbergh are similarly inapplicable since Habitica would not be subject to their relational ethics. ${ }^{26}$ Thus, these analyses provide little reason to assume Habitica is or could be other in the ethically relevant sense that the human Other is. How, then, should we understand its apparent alterity and its ethical relevance? Ironically, this may again require a detour to the work of Don Ihde, who strips technological alterity of its ethical connotations.

For Ihde (1990), alterity relations take shape "as relations to or with technologies, to technology-as-other" (p. 98). However, while Ihde admits to being inspired by Levinas' work in conceptualizing alterity relations (ibid.), he is quick to divest them of the former's ethical gravity. He claims that alterity relations with technology are characterized by technologies exhibiting "quasi-otherness", which is "stronger than mere objectness but weaker than the otherness found within the animal kingdom or the human one" (ibid. p. 100). ${ }^{27}$ A relation with such a technological quasi-other can, according to Ihde, actualize in different ways. First, he acknowledges being fond of technological artifacts, like an old motorcycle one is fixing up and cherishes. One may also be fascinated by a technology that seems to take on a life of its own in quasianimation, such as a spinning top. Lastly, and most of interest here, there are technological objects by which I am challenged, like a difficult computer game, and which invite me to action in response to said challenge.

Interestingly, Ihde's hesitance to import Levinas' ethics into his conception of alterity relations can be justified by linking them to the appropriate human-world relations in Levinas, which are not always ethical. Fondness of an artifact can be seen as underpinned by the repeated sensuous enjoyment of the artifact, the possibility of "taking it in." 28 Such enjoyment is indispensable to Levinas' conception of ethics but is called into question in it. Fascination may in turn be connected to Levinas' reflections on objects of art that draw in my gaze but do so through a (possibly enjoyable) esthetic rather than ethical effect. As such, by process of elimination, Levinasian alterity and ethics in alterity relations with technology, if any, would have to be found in the challenging alterity relations with technology. There are at least two distinct ways in which a technology may challenge me, with different Levinasian connections and relevance for subjectivation. The first way is an invitation to labor, where I engage in the world with the promise of postponed enjoyment (Levinas 1969). Such labor may very well be playful, as in interaction with Ihde's "virtual competitor" in a computer game, or might be frustrating. I may even enjoy the labor itself, since "[o]ne can like one's job, enjoy these material gestures and the things that permit the accomplishing of

\footnotetext{
25 This should not be surprising, given that Harman is mainly inspired by Heidegger's work, of which much of Levinas' oeuvre is already a severe critique.

${ }^{26}$ We also have doubts concerning the ease with which Coeckelbergh and Gunkel brush aside other constitutive parts of Levinas' phenomenology, i.e., enjoyment, suffering, hunger, vulnerability, substitution, fecundity, etc., which would also have to be overcome, replaced or shown idiosyncratic in the face of the "machine question" without reading alterity in terms of ontological difference.

${ }^{27}$ Ihde focuses on the extent to which technologies can be a positive content of experience, a presence in their own right. He gives no indication that this "scale" of alterity implies an intermediate position in terms of moral patienthood for technologies with which we are in alterity relations.

${ }^{28}$ Verbeek's (2005) "sensorial" turn in thinking a material aesthetics in design appears compatible with this connection between aesthetics and sensuous enjoyment.
} 
them. One can transform the curse of labor into sport" (ibid. p. 133). However, such a challenge would not motivate me to change myself or move beyond (aiming at) my own enjoyment. In contrast, a technological artifact may challenge me by confronting me with my own failures and/or shortcomings. ${ }^{29}$ Whether I am unable to beat that game level for the umpteenth time, I cannot figure out what is wrong with my motorcycle, or I have failed to do my daily tasks in Habitica, I am confronted with myself, and this may motivate me to better myself by training, learning, and/or discipline, respectively.

This dynamic of confrontation and motivation runs roughly parallel to Levinas' conception of the Other calling me to responsibility and motivating me to better myself in the name of justice. Thus, it seems that it is here, if anywhere, that a link between Habitica's alterity, responsibility and subjectivation is to be found. And yet, how is this possible if technologies are not infinitely Other? In the next section, we work towards a hypothesis.

\subsection{Technology's Finite Alterity and Responsible Subjectivity}

Levinas' own work provides few resources for thinking the alterity of technological objects. As Wellner (2014) points out, Levinas' "tool analysis" focuses on adding an axiological dimension to Heidegger's instrumental sphere of $\mathrm{Zu}$ - and Vorhandenheit (Heidegger 1962): "[t]he enjoyment of a thing, be it a tool, does not consist simply in bringing this thing to the usage for which it is fabricated [...] but also in suffering or rejoicing over this operation" (Levinas 1969 p. 133). Doing so, Levinas focusses more on $z u$ - than vorhandenheit, or - in Ihde's words - embodiment rather than alterity relations. Nevertheless, joy is not excluded from alterity relations with technologies. In fondness and fascination, I enjoy technological objects while not having the boundaries between the I and the enjoyed blur to the point of insignificance (Levinas $1969 \mathrm{pp}$. 187-188). On the other hand, challenging technologies operate through a frustration of my enjoyment, either by its postponement until I engage in labor or by confronting me and questioning my right to it, as Habitica does. And this is where the difficulty lies: in Levinas, such questioning is reserved for the face of the human Other (e.g., Levinas 1969 p. 73), in which infinite alterity presents itself and defies my ability and right to power and enjoyment (p. 198).

Still, there might be room for nonhuman others not ultimately destined for my sensuous appetites. In a late interview, Levinas was asked about the possibility of the face of nonhuman animals. He admitted that "[o]ne cannot entirely refuse the face of an animal. It is via the face that one understands, for example, a dog" (Levinas $1988 \mathrm{p}$. 169). ${ }^{30}$ However, "[t]he phenomenon of the face is not in its purest form in the dog. [...] But it also has a face". The dog's face does not present itself with the same extreme frailty and authority that characterizes the face of the human other. Nevertheless, there is a pity to be had for a dog (ibid. p. 172), which means that there are nonhuman faces that can confront me and elicit a response.

\footnotetext{
${ }^{29}$ This does not mean that an artifact cannot affect me in both ways. Just like I can engage in embodied relations with a hammer, only to have it evolve into an alterity relation when it breaks, I may, for example, be challenged to labor only to be confronted afterwards with myself and my inability to succeed due to my own lack of ability or practice.

${ }^{30}$ Levinas' selection of the dog as an example is no coincidence. In his essay "The Name of a Dog, Or Natural Rights," he describes a dog named Bobby as "the last Kantian in Nazi Germany" (Levinas 1990 p. 153).
} 
In the same interview, Levinas claims that such pity is possible only because I have already seen the face of the human Other, which "is completely different and only afterwards do we discover the face of an animal" (p. 172). By being put into question by the human Other (Levinas 1981 p. 56), my subjectivity is first structured as responsibility, I become "responsibility through and through" (Levinas 1996 p. 12). It is because I can suffer for the human Other's suffering that I can recognize suffering in nonhuman others and receive obligations towards them. Yet, this raises the question: how finite can a nonhuman other be and still elicit a response? And does this necessarily entail moral aspects such as pity or charity? According to Wellner (2014), it does not. ${ }^{31}$ She investigates how technologies, and especially interactive screen technologies like the smartphone, can indeed question me and elicit responses because they exhibit what she calls a "quasi-face." The technological quasi-face "acts like a face that requires a response, but is not a face" (p. 311), and it does not transcend the ontological towards the ethical. Rather, the reason it can serve as such is because the way I relate to such objects shares concrete characteristics with my relation to human Others; the technological interface becomes "humanized." 32 For example, when my motorcycle breaks down, I enter into an alterity relation with it. It surprises me and interrupts my enjoyment, it exhibits frailty (but not suffering), and I cannot simply bend it to my will and make it work. Getting back to riding requires sensitivity to its specific constitution, careful listening, and handling it with appropriate patience and care. While I do not pity the thing, my relation bears some superficial similarities to relations with fellow humans, which is only possible because my very subjectivity is already structured as responsibility. When working with interactive screen technologies, like when using Habitica, these similarities are expanded because the screen, i.e., the quasi-face, represents an interiority behind the screen, is a communicative interface, is usually based in language, presents questions and responses to input, and is never neutral or non-normative (Wellner 2014 p. 313).

Despite all this, neither the call of the quasi-face nor the response to it would, by themselves, be ethical. But then why does the confrontation with Habitica seem so morally loaded? Why does it induce shame and motivate me to improve myself through ascetic practice? To understand this, it is important to realize that while Habitica calls me into question, I do not owe it anything. It calls for a response, but not on its own behalf. In failing to keep to my own commitments (now translated into tasks, dailies, and habits) I have either failed my (past) self or others (including party members who lost health points). In Levinasian terms, technologies such as these cannot be hungry. They can only remind me of the existence and urgency of hunger and my responsibilities in a world in which suffering persists. Concretely, the Habitica app fulfills the confronting function by its quasi-face ánd making my prior commitments and responsibilities to others present and urgent. While procrastinating, the latter disappeared into the background of my enjoyable existence. Habitica throws them squarely back into my world and demands a response on their behalf, a response that now has ethical gravity.

\footnotetext{
${ }^{31}$ Nevertheless, the significance of such a non-morally loaded alterity relation with technology would remain questionable for Levinas. As he remarks, "[s]ignification, the one-for-the-other, has meaning only among beings of flesh and blood" (Levinas 1981 p. 74).

32 This is different from anthropomorphizing the artifact. Instead of ascribing human characteristics to it, the quasi-face focuses on similarities in the way I concretely relate to fellow humans and to artifacts.
} 
With this, it is possible to explain how Habitica can call me to responsibility without endowing the phone app or its avatars with the sanctity of infinite alterity or claiming that they somehow acquire moral patienthood in virtue of their quasi-otherness. Both confronting but non-ethical alterity relations with technology on the one hand and the moral gravity of dailies, habits, and tasks (as mediated forms of my responsibilities to others) are compatible with a Levinasian notion of subjectivity that, as is the hypothesis being explored here, underlies subjectivation.

\section{Habitica and Subjectivation: Serious Gaming}

With all of the above, we have shown how Habitica is able to play an active role in technologically mediated subjectivation by operating as a "technology of technologies of the self." In line with Foucault's reflection on the writing of letters and notebooks, Habitica can play this role because it puts the subject in a critical relation with itself through confronting it with the alterity of a representation of the subject, of others (real or emulated), or of the technology not functioning the way the subject intends. To better understand these confronting relations, reflections on Levinasian subjectivity revealed the ethical link between confrontation, shame, and the responsibility to engage in subjectivation, as well as the way in which technological artifacts, by virtue of their quasi-otherness, can induce shame and call the subject to engage in subjectivation despite the former being nonhuman.

However, was Habitica not supposed to represent the "gamified life"? Does the analysis presented here do away with gamification as an explanation for why Habitica works? Not necessarily, but it does position Habitica's gamification aspects as part of the general economy of subjectivation. On the one hand, the punishment and reward structure of the "gamified life" facilitate self-discipline by reframing ascetic practices of the self as distinct units of work. These can be challenging and hold a promise of enjoyment (or the frustration thereof) ${ }^{33}$ and thus lower the subjective threshold for engaging in ascetic practices. On the other hand, these actions become part of a larger project of subjectivation by virtue of role-playing aspects such as leveling and gaining virtual skills, which represent and virtually realize the larger project of care of the self. In this way, gamification can indeed contribute to the technologically mediated care of the self. Nevertheless, some vigilance is advised. I limit the discussion here to two points of caution, in line with the Foucaultian and Levinasian outlooks employed above.

First, some worry that gamification is often used, not as part of Foucaultian practices of freedom, but rather to subtly predict, control, and steer behavior of users based on a behaviorist, dopamine-driven account of humanity. Engaging in a "gamified life" would normalize this reductive anthropology and teach users to abide by and habituate a set of implicit but nevertheless imposed rules. In other words, gamification may represent a seductive form of Foucaultian biopolitics (Pacewicz 2015; Wencel 2015). Habitica avoids some of these pitfalls by having the subject integrate its own rules and aspirations. However, it still risks normalizing the underlying view of the subject.

\footnotetext{
${ }^{33}$ It is noteworthy that some of the rewards in Habitica concern virtual possessions (gold pieces, armor, weapons, etc.) and that Levinas' use of jouissance partly refers to the joy of (the use of) possessions.
} 
Secondly, there is a Levinasian worry that games might not be an appropriate medium for subjectivation, given the latter's ethical significance. As he explains, "[g]ames [...] lack seriousness. They are levity itself. One can drop them at any moment. [...] It is a reality that leaves no traces" (Levinas 1978 p. 26). For subjectivation, then, a mere game will simply not do. If subjectivation is the goal, the game must turn serious, turn into work. ${ }^{34}$ It is Game Over! There are now stakes. That is, I am at stake, for my own and others' sake.

As such, the analysis presented in this paper suggests that if gamification employed the design of technologies that support practices of the self, addressing these worries is paramount in doing so.

\section{Conclusion}

This paper set out to analyze the potential role of technology in mediation theory's ethics of subjectivation. In terms of the latter, technologies are usually seen as power structures to which one relates through subjectivation. However, we have focused here on another, hitherto underemphasized role of technologies: as explicitly supporting this process of relating to other technologies by mediating one's critically relating to oneself in a technological milieu.

The gamified To-Do list app "Habitica" served as a modern example of a "technology of technologies of the self," which indicated the importance of self-discipline and self-writing, but also of enjoyment and confrontation. Based on this description, four ways were identified in which a technology like Habitica might invite a critical relation to oneself. The confronting nature of these relations, whether with representations of oneself, with others or with the app itself, led to a Levinasian account of confrontation and how it relates to subjectivation. Not only does it show the connection between enjoyment, confrontation, subjectivity and the responsibility to work on oneself, but it also helps to explain how a technology like Habitica can call us to responsibility in virtue of its quasi-otherness. That is, it is only because our confrontation with fellow humans has already rendered us responsible subjects that technologies can emulate such evocations of responsibility.

It remains unanswered to what extent inconsistencies between the Foucaultian and Levinasian accounts presented above could be adequately resolved towards a more unified theory of subjectivation in mediation theory. That is, their respective accounts of embodiment, the precise origins of subjectivity, and, importantly, the priority of care between self and others remain contentious. Nevertheless, both authors also emphasize the role of others in the dawning of subjectivity, the passivity of embodied existence and its susceptibility to subjectivating influences, the significance of confrontation and shame, and the responsibility to engage in self-development. In this overlap, at least, some further cross-fertilization and harmonization may be found, both in terms of Foucaultian elucidations of Levinas' political subject as well as Levinasian, ethical foundations for Foucault's embodied existence. For now, both can at least be said to provide crucial insights into the role of concrete technologies in subjectivation.

\footnotetext{
${ }^{34}$ See footnote 21 .
} 
Additionally, gamification was shown to take up its own peculiar place in technologically mediated subjectivation. That is, it is able to render present, structure and support ascetic practices by objectifying them in habits, dailies and tasks and by lowering their relative "cost," promising either enjoyment or its frustration in case users of the technology fail to engage in them. However, it does not account for confrontation and the responsibility to subjectivate. As such, gamification plays a relatively small part in the explanation of why Habitica functions as a technology for self-care. Nevertheless, it shows promise for those specific aspects, as long as the specter of biopolitics, gamification's impoverished anthropology, and the natural levity of games can be curtailed in the design for future "technologies of technologies of the self."

Indeed, both gamification and the different ways in which technology can constitute a critical relation to oneself could provide additional inspiration for future "design for subjectivation." That is, another link between mediation theory's ethics of subjectivation and its prescriptions for design has been laid bare: design can not only aim for technologies to which one can more easily critically relate in subjectivation (Verbeek 2011), but it can now also more purposefully create technologies to support that very process.

Funding Information This work was supported by The Netherlands Organization for Scientific Research (NWO) [Nederlandse Organisatie voor Wetenschappelijk Onderzoek (NL)] under Grant No. 277-20-006.

Open Access This article is licensed under a Creative Commons Attribution 4.0 International License, which permits use, sharing, adaptation, distribution and reproduction in any medium or format, as long as you give appropriate credit to the original author(s) and the source, provide a link to the Creative Commons licence, and indicate if changes were made. The images or other third party material in this article are included in the article's Creative Commons licence, unless indicated otherwise in a credit line to the material. If material is not included in the article's Creative Commons licence and your intended use is not permitted by statutory regulation or exceeds the permitted use, you will need to obtain permission directly from the copyright holder. To view a copy of this licence, visit http://creativecommons.org/licenses/by/4.0/.

\section{References}

Behrent, M. C. (2013). Foucault and technology. History and Technology, 29(1), 54-104.

Bergen, J. P. (2017). Responsible innovation in light of Levinas: Rethinking the relation between responsibility and innovation. Journal Responsible Innovation, 4(3).

Blohm, I., \& Leimeister, J. M. (2013). Gamification: Design of IT-based enhancing services for motivational support and behavioral change. Business and Information Systems Engineering, 5(4), 275-278.

Borgmann, A. (1984). Technology and the character of contemporary life: A philosophical inquiry. Chicago: University of Chicago Press.

Bottenberg, F. (2015). Searching for Alterity: What can we learn from interviewing humanoid robots? In R. Rosenberger \& P.-P. Verbeek (Eds.), Postphenomenological investigations: Essays on human-technology relations (pp. 175-189). Lanham: Lexington Books.

Coeckelbergh, M. (2013). Human being @ risk: Enhancement, technology, and the evaluation of vulnerability transformations. Dordrecht: Springer.

Coeckelbergh, M. (2014). The moral standing of machines: Towards a relational and non-Cartesian moral hermeneutics. Philosophy and Technology, 27(1), 61-77.

Crawford, K., Lingel, J., \& Karppi, T. (2015). Our metrics, ourselves: A hundred years of self-tracking from the weight scale to the wrist wearable device. European Journal of Cultural Studies, 18(4-5), 479-496.

Derrida, J. (2008). The animal that therefore I am. New York: Fordham University Press. 
Deterding, S., Dixon, D., Khaled, R., \& Nacke, L. (2011). From game design elements to Gamefulness: Defining Gamification. In Proceedings of the 15th International Academic MindTrek Conference on Envisioning Future Media Environments - MindTrek (11th ed., pp. 9-15). Tampere: ACM.

Dorrestijn, S. (2012). The design of our own lives: Technical mediation and subjectivation after Foucault (University of Twente). University of Twente.

Dorrestijn, S. (2017). The Care of our hybrid selves: Ethics in times of technical mediation. Foundations of Science, 22(2), 311-321.

Fornet-betancourt, R., Becker, H., Gomez-müller, A., \& Gauthier, J. D. (1987). the ethic of care for the self as a practice of freedom: An interview with michel foucault on January 20, 1984. Philosophy \& Social Criticism, 12(2-3), 112-131.

Foucault, M. (1973). The birth of the clinic: An archaeology of medical perception. New York: Pantheon Books.

Foucault, M. (1977). Discipline and punish: The birth of the prison. New York: Vintage Books.

Foucault, M. (1982). The subject and power. Critical Inquiry, 8(4), 777-795.

Foucault, M. (1986). The history of sexuality: The Care of the Self. New York: Pantheon Books.

Foucault, M. (1989). The order of things: An archeology of the human sciences. London: Routledge.

Foucault, M. (1990). The history of sexuality: The use of pleasure. New York: Vintage Books.

Foucault, M. (1997). Ethics : Subjectivity and truth. In P. Rabinow (Ed.), The essential works of Foucault (pp. 1954-1984). New York: The New Press.

Foucault, M. (2005). The hermeneutics of the subject: Lectures at the Collège De France, 1981-1982. New York: Palgrave-Macmillan.

Gunkel, D. J. (2012). The machine question: Critical perspectives on Ai, robots, and ethics. Cambridge: MIT Press.

Gunkel, D. J. (2018). The other question: Can and should robots have rights? Ethics and Information Technology, 20, 87-99.

Hamari, J., Koivisto, J., \& Sarsa, H. (2014). Does gamification work? - A literature review of empirical studies on gamification (pp. 3025-3034). Waikoloa: 47th Annual Hawaii International Conference on System Sciences.

Harman, G. (2002). Tool-being: Heidegger and the metaphysics of objects. Open Court Publishing.

Heidegger, M. (1962). Being and Time. New York: Harper.

Heidegger, M. (1977). The question concerning technology. In W. Lovitt (Ed.), The question concerning technology and other essays (pp. 3-35). New York: Harper.

Hofmann, B., \& Svenaeus, F. (2018). How medical technologies shape the experience of illness. Life Sciences, Society and Policy, 14(1), 3.

Hofmeyr, A. B. (2003). Self-created of other-invoked? Foucault and Levinas on how to become ethical. Phronimon, 1, 40-61.

Hofmeyr, A. B. (2006). The meta-physics of Foucault's ethics: Succeeding where Levinas fails. South African Journal of Philosophy, 25(2), 113-125.

Ihde, D. (1990). Technology and the Lifeworld. Bloomington, IN: Indiana University Press.

Introna, L. D. (2010). The 'measure of a man' and the ethos of hospitality: Towards an ethical dwelling with technology. AI \& SOCIETY, 25(1), 93-102.

Kudina, O., \& Verbeek, P.-P. (2018). Ethics from within: Google glass, the Collingridge dilemma, and the mediated value of privacy. Science, Technology, \& Human Values, 44(2), 291-314.

Latour, B. (1992). Where are the missing masses? The sociology of a few mundane artifacts. In W. E. Bijker \& J. Law (Eds.), Change (pp. 225-259). Boston: MIT Press.

Latour, B. (1993). We Have Never Been Modern. Boston: Harvard University Press.

Levinas, E. (1969). Totality and infinity: An essay on exteriority. Pittsburgh: Duquesne University Presss.

Levinas, E. (1978). Existence and existents. Dordrecht: Kluwer Academic Publishers.

Levinas, E. (1981). Otherwise than being or beyond essence. Dordrecht: Kluwer Academic Publishers.

Levinas, E. (1986). The trace of the other. In M. Taylor (Ed.), Deconstruction in context: Literature and philosophy (pp. 345-359). Chicago: University of Chicago Press.

Levinas, E. (1987a). Collected philosophical papers. Dordrecht: Martinus Nijhoff Publishers.

Levinas, E. (1987b). Time and the other. Pittsburgh: Duquesne University Presss.

Levinas, E. (1988). The paradox of morality: An interview with Emmanuel Levinas. In R. Bernasconi \& D. Wood (Eds.), The provocation of Levinas: Rethinking the other. London: Routledge.

Levinas, E. (1990). Difficult Freedom: Essays in Judaism (S. hand, Ed.). Baltimore: The Johns Hopkins University press.

Levinas, E. (1994a). Sur l'Esprit de Genève. In Les Imprévus de l'histoire. Saint-Clément-de-Rivière: Fata Morgana. 
Levinas, E. (1994b). The rights of man and the rights of the other. In Outside the Subject. Stanford: Stanford University Press.

Levinas, E. (1996). Basic Philosophical Writings (a. T. Peperzak, S. Critchley, \& R. Bernasconi, Eds.). Bloomington, IN: Indiana Univeristy press.

Levinas, E. (1998). Secularization and hunger. Graduate Faculty Philosophy Journal, 20/21(2/1), 3-12.

Levinas, E. (2000). God, death, and time. Stanford: Stanford University Press.

Levinas, E. (2003). Humansim of the other. Oxfordshire: Marston Book Services Ltd..

Levinas, E., Bouchetoux, F., \& Jones, C. (2007). Sociality and money. Business Ethics: A European Review, 16(3), 203-208.

Lewis, R. S. (2018). Hello Anthropocene, goodbye humanity. Glimpse, 19, 79-87.

Mayes, C. R. (2015). Revisiting Foucault's "normative confusions": Surveying the debate since the Collège de France lectures. Philosophy Compass, 10(12), 841-855.

Oksala, J. (2005). Foucault on freedom. Cambridge: Cambridge University Press.

Oksala, J. (2010). Foucault's politicization of ontology. Continental Philosophy Review, 43, 445-466.

Pacewicz, K. (2015). The dopamine loop and its discontents. Analysis of "Gamification by design" as biopolitical power/knowledge. In Kopeć, J. J. \& Pacewicz, K.(Eds.), Gamification. Critical Approaches. (pp. 27-39). Warsaw: The faculty of "Artes Liberales”, University of Warsaw.

Pantzar, M., \& Ruckenstein, M. (2017). Living the metrics: Self-tracking and situated objectivity. Digital Health, 3, 1-10.

Robson, K., Plangger, K., Kietzmann, J. H., McCarthy, I., \& Pitt, L. (2015). Is it all a game? Understanding the principles of gamification. Business Horizons, 58(4), 411-420.

Rosenberger, R., \& Verbeek, P.-P. (2015). A field guide to Postphenomenology. In R. Rosennbergen \& P.-P. Verbeek (Eds.), Postphenomenological investigations: Essays on human-technology relations (pp. 9-41). Lanham: Lexington Books.

Ruckenstein, M. (2014). Visualized and interacted life: Personal analytics and engagements with data doubles. Societies, 4(1), 68-84.

Seaborn, K., \& Fels, D. I. (2015). Gamification in theory and action: A survey. International Journal of Human Computer Studies, 74, 14-31.

Sharon, T., \& Zandbergen, D. (2017). From data fetishism to quantifying selves: Self-tracking practices and the other values of data. New Media and Society, 19(11), 1695-1709.

Skinner, B. F. (1938). The behaviour of organisms: An experimental analysis. New York: Appleton-Century.

Steffen, P., Linehan, C., Kirman, B., \& Roche, B. (2015). Gamification as behavioral psychology. In S. P. Walz \& S. Deterding (Eds.), The Gameful world: Approaches, issues, applications (pp. 81-105). Cambridge: MIT Press.

Van Den Eede, Y. (2015). Tracing the tracker: A Postphenomenological inquiry into self-tracking technologies. In Postphenomenological Investigations: Essays on Human-Technology Relations (pp. 143-158).

Verbeek, P.-P. (2005). What things do - philosophical reflections on technology, agency and design. University Park: The Pennsylvania State University Press.

Verbeek, P.-P. (2008). Cyborg intentionality: Rethinking the phenomenology of human-technology relations. Phenomenology and the Cognitive Sciences, 7(3), 387-395.

Verbeek, P.-P. (2011). Moralizing technology: Understanding and designing the morality of things. Chicago: The University of Chicago Press.

Wellner, G. (2014). The quasi-face of the cell phone: Rethinking alterity and screens. Human Studies, 37(3), 299-316.

Wellner, G. (2018). From cellphones to machine learning. A shift in the role of the user in algorithmic writing. In A. Romele \& E. Terrone (Eds.), Towards a philosophy of digital media (pp. 205-224). Cham: Palgrave Macmillan.

Wencel, J. (2015). Gamified vs. non-Gamified space in video games: A biopolitical approach. In J. Kopeć \& K. Pacewicz (Eds.), Gamification. Critical Approaches (pp. 69-82). Warsaw: The faculty of "Artes Liberales", University of Warsaw.

Publisher's Note Springer Nature remains neutral with regard to jurisdictional claims in published maps and institutional affiliations. 